\title{
How Does Social Science Education Drive Marketing Mindset to Shape Entrepreneurial Interest?
}

\author{
Harti Harti ${ }^{1, *}$ Nasution Nasution ${ }^{1,}$ Nugroho H. Purnomo ${ }^{1,}$ Andre D. Witjaksono ${ }^{1,}$ \\ Norida C. Sakti ${ }^{1,}$ Ramlee b. Ismail ${ }^{2}$ Mohd A. b. M. Noor ${ }^{2}$ \\ ${ }^{1}$ Universitas Negeri Surabaya, Indonesia \\ ${ }^{2}$ Universiti Pendidikan Sultan Idris, Malaysia \\ *Corresponding author.Email: harti@unesa.ac.id
}

\begin{abstract}
The study of entrepreneurial interest and marketing mindset were limited to entrepreneurial education and has not taken into account a broader scientific family, specifically the social sciences. Previous studies also omitted to mention the influence of external environments on the social science education curriculum and one's way of thinking and mindset. In examining entrepreneurial interest, studies have mainly focused on the determinants of entrepreneurial intention with less focus on the cognitive, conative and affective aspects in practicing entrepreneurship. This paper aims to address conceptually, how social science education drives the marketing mindset to shape entrepreneurial interest. This paper laid down a discussion of the previous literature and provided a major argument on social science education, marketing mindset, and entrepreneurial interest. The method of the study is a qualitative literature review. Finally, this paper argues that the external environments influence the social science education and marketing mindset; and marketing mindset mediated the influence of social science education on entrepreneurial interest. This study contributes to the existing literature on the conceptualization of social science education influence on the marketing mindset and then on entrepreneurial interest by engaging the external factors, which is missing in the prior studies. However, empirical studies are needed to examine this argument.
\end{abstract}

Keywords: Social science education, Marketing mindset, External environments, Entrepreneurial interest, Conceptual paper.

\section{INTRODUCTION}

Policymakers in both developed and developing nations are concerned about developing new businesses [1-3]. The primary reason is that small and medium enterprises offer potential jobs, which may result in a significant benefit to economic development and growth, as well as community welfare [4-6]. Prior research has invariably found a link between entrepreneurial education, and the formation of new businesses [7-11]. According to the findings, entrepreneurial education is critical in defining entrepreneurial mindset, knowledge, interest, and intention to be an entrepreneur [12]. Entrepreneurial interest from the younger generation can remedy unemployment, particularly given the high laborforce participation rate of educated persons [10]. Because it has been claimed to play a vital role in the formation of new businesses, entrepreneurial or business education, which belongs to the social science family, has piqued the interest of academics [13,14]. However, in the study of entrepreneurial interest and marketing mindset, most research was limited to entrepreneurial education and has not considered a broader scientific family, specifically the social sciences. The social sciences, with their emphasis on human behavior and the generation of cumulative knowledge [15], offer tremendous potential to inform, encourage, and produce social innovation for the formation of a social enterprise or generating social impact [16]. Utilizing the potential of a diverse variety of social science disciplines, such as economics, sociology, psychology, political science, law, public policy, anthropology, geography, and history, enable students to provide new perspectives to pressing public-sector issues [17] or generating marketing ideas.

Previous studies also omitted to mention the influence of external environments on the social science education curriculum $[18,19]$ and one's way of thinking and 
mindset. Factors like social relationships, community, education, technology, geography, culture, economic conditions, and political systems will expose someone to various life experiences, resulting in varying perspectives of marketing and entrepreneurial activities as a whole. Someone with limited ability to recognize consumer behavior, the market, and the current trend might struggle and find that entrepreneurial activity is complex, highrisk, and unappealing. In contrast, someone with a good marketing mindset might have the confidence to practice entrepreneurship and thus increasing their interest in entrepreneurship.

In examining entrepreneurial interest, studies have mainly focused on the determinants of entrepreneurial intention with less focus on the cognitive, conative and affective aspects in practicing entrepreneurship [20-31]. Therefore, this paper emphasizes an individual's enthusiasm to start an entrepreneurial activity in the future [32,33]. Although the entrepreneurial intention is the first step in forming a new company in the entrepreneurial process, persons with a strong passion or interest in entrepreneurship have a higher probability of owning a business start-up in the future. As a result, research is scarce in the literature that gives findings regarding factors of entrepreneurial interest, particularly among students. Thus, this paper addresses how social science education drives the marketing mindset to shape entrepreneurial interest. The fundamental reason is that university students are expected to build a business startup instead of middle-class workers [12].

\section{LITERATURE REVIEW}

\subsection{Social Science Education, Marketing Mindset, and Entrepreneurial Interest Relationship Model Development}

Literature on education, mindset, and interest predominantly employs theories in psychology, among others are human capital theory [34], entrepreneurial event theory [35], social learning theory [36], ), and theory of planned behaviour [37], ) also the social constructivism approach [38-41] in relation to the external environment variable. This paper establishes a conceptual model that integrates social science education, external environment, and marketing mindset based on these theories. We argue that these variables must be examined concurrently better to understand their combined influence on the entrepreneurial interest.

To be able to earn profit and stay viable in the long run, a business needs to collect revenue and marketing is one of the ways. Seeing as the marketing mindset consists of trend recognition, good marketing strategy, and understanding consumer behavior, we reckon an individual with a good marketing mindset can bring success to their venture. Thus, a marketing mindset increases the confidence to practice entrepreneurial activities. Nevertheless, not every individual will be interested in entrepreneurship. We argue that external environments and social science education are essential for individuals to succeed in a marketing mindset

Possession of a marketing mindset enables these individuals to effectively and successfully promote and sell their products to bring in revenue and their social science education can also affect how good their marketing mindset is. Similar to the impact of external environments on individuals, we argue that not all individuals have similar environments, thus, not all students can develop a marketing mindset. The degree of marketing mindset affects the possibilities of an individual to have entrepreneurial interest despite having good social science education and supporting external environments. Figure 1 below depicts the conceptual framework model, described further in the following sections.

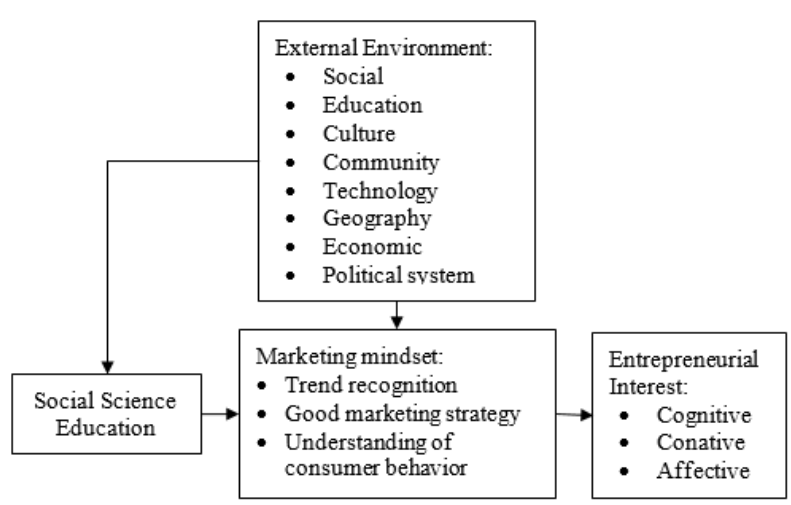

Figure 1 Conceptual framework model.s

\subsection{Propositions Development}

\subsubsection{Marketing Mindset and Entrepreneurial Interest}

Human minds are inventive and entrepreneurial; when chances and rewards are possible, natural human drives encourage the extraordinary ways of thinking and acting [42]. The concept of mindset was employed as a time period in the topic of learning about the human mind; it demonstrates the human mind's ability to distinguish the right effects in connection to actuality and reality. It is a terminology associated with cognitive psychology, or as it is sometimes referred to as cognitive psychology, which is a subfield in psychology whose mission is entirely based on exploring individual mental models strategies, as this science studies how people think, perceive, communicate, and solve problems. Cognitive psychology also acknowledges the presence of internal states of thought, for example: perception, attitude, desire, intention, knowledge, and motivation.

A shift in attitude has a multiplier impact on individual lifestyle, character, and behavior changes. Because the trade-in mentality is a long-term system with 
certain unwritten principles that eventually lead to changes in behavior, it must be adjusted in a way that can be reflected and demonstrated in the goal individual's actions [43]. It is worth emphasizing here the beneficial role that a marketing mindset may play in encouraging the creativity and innovation of individuals. Marketing mindset consists of: an image of future market demands, a comprehension of the businesses model, a relationship that exists in the market that demonstrates some causality or goal outcomes, a depiction of essential aspects of interconnections in the value stream, or an illustration of the chain of activities in the strategic design [44], those includes trend recognition, good marketing strategy, and an understanding of consumer behavior.

Marketing mindset, in particular, depicts the comprehension and interpretation of information obtained and guides the behavior of decision-makers, which includes their market-oriented actions [45]. Lee and Kotler [46] highlighted the following characteristics of an effective marketing mindset:

- Adopting a customer-centric mindset. Marketing understands the needs of consumers and how to address their difficulties. This should be either recognizing the market demands and satisfying these desires to attract new consumers or resolving present customers' problems to keep them.

- Segmenting, targeting, and positioning. Customer segmentation enables marketers to employ a more methodical technique when preparing for the future. This results in the more effective use of marketing resources, resulting in creating a more finely tailored advertising program.

- Utilize the marketing mix very well. When most individuals hear or use the phrase "marketing," they have a limited understanding of what it entails. When asked what they think of when they think of marketing, most individuals would say direct selling, advertising, public transport boards, and outdoor billboards. In truth, they are just a few of the aspects of advertising instruments that should be considered: promotion. In the finest marketing strategy scenarios, promoting decisions are no longer taken into account until decisions are made for each of these policies, which are the decisions that produce the offer to be pushed: product, price, and distribution. Marketers with a marketing mindset understand their clients' desires and needs and translate them into marketing products (goods and services). They provide a genuine cost to the customer, allowing the organizations to improve their marketing effectiveness, find and develop new markets, and be creative in delivering fantastic products and services.

Due to the paucity of literature that explicitly examines the relationship between the marketing mindset and entrepreneurial interest, we will associate the marketing mindset with entrepreneurial mindset although it is slightly different. Fayolle and Linan [47] and
Akmaliah et al. [48] identified entrepreneurial mindset as a state of mind that directs people's behaviour toward entrepreneurship-related activities and outcomes. Furthermore, those researchers claimed that the entrepreneurial mindset is strongly related to individuals states of mind (conscious or sub-conscious) or how one thinks or the viewpoint through which one perceives the world, impacting one's dispositions for entrepreneurship and success in these activities. Shepherd et al. [49] corroborate this viewpoint and have proven that the entrepreneurial mindset provides prospective insights into the many outcomes and situations required for entrepreneurial research, including entrepreneurial interest.

As mentioned in the previous section, there are several theoretical grounds for entrepreneurial interest in relation to marketing mindset, among others are entrepreneurial event theory [35], social learning theory [36], and theory of planned behaviour [37]. According to the theory of entrepreneurial event [35], the desire to be an entrepreneur is dependent on the individual's perception of entrepreneurship's desirability and feasibility. Before forming an interest and engaging in entrepreneurship, an individual must first perceive it as desirable. Feasibility refers to an individual's view of accessible resources, such as knowledge, financial 'safety net', and skill. On the other hand, desirability refers to an individual's attitude, values, and emotions, which are influenced by their social environment, including family, friends, and co-workers.

Bandura's [36] social learning theory, often known as social cognitive theory, describes human behavior as the interactions of personal, behavioral, and environmental variables. The emphasis of personal variables is on whether one has low or high self-efficacy. Behavioral factors refer to the individual's reaction to a specific behavior, good or bad. Environmental variables capture the impact of the environment on the performance of an activity.

While other theories, such as the theory of planned behaviour [37], predict that intention is influenced by three factors: attitude, subjective norm, and perceived behavioural control. These elements give birth to intention and, as a result, participation in a specific behavior. It assesses how much importance an individual places on a specific sort of behavior. On the other hand, subjective norm refers to the social pressure or influence exerted by someone's parents, friends, and other respected family members to engage or refrain from engaging in an act or behavior. Perceived behavioural control describes a person's impression of their capacity to conduct a behavior and whether or not resources are available to do so. The TPB has been used to model entrepreneurial intention in most research. This is because the TPB is the most recent behavioral theory in 
the literature and incorporates factors from previous theories of entrepreneurial intention.

There are conflicting findings on the elements that impact entrepreneurial intent. In most situations, not all TPB factors substantially impact the intention to run a firm. For example, Iqbal et al. [25], found that attitude and perceived behavioural control are key predictors of entrepreneurial intention, with a substantial positive effect, when they examined answers of undergraduate students to the topic of entrepreneurial interest. As a result, the inference is that subjective norm does not influence on entrepreneurial intention among university undergraduate students. Simple regression analysis between entrepreneurial intention and TPB factors gave study conclusions. In similar research, Tong et al. [23] used multiple regression analysis to show that the need for accomplishment, family business background, and subjective norm influence entrepreneurial intention. The findings show that students will opt to become entrepreneurs if there is a desire for accomplishment, if they come from a business-oriented household, and if close persons such as family members and friends encourage them.

Grounded on these theories, we propose that someone with limited ability to recognize consumer behavior, the market, and the current trend might struggle and find that entrepreneurial activity is complex, risky, and unattractive. In contrast, someone with a good marketing mindset might be confident to practice entrepreneurship. Thus, it might build their interest in entrepreneurship. Based on the explanation, we propose: $P 1=$ Marketing Mindset has a positive and significant influence on Entrepreneurial Interest.

\subsubsection{Social Science Education, Marketing Mindset, and Entrepreneurial Interest}

Social Science is the study of society and human behaviors. The study of people and their relationships and interaction with one another, with their political and social institutions, and with their environment is what social science is all about. As a result, Social Science Education significant offers a diverse set of courses and disciplines. Students are required to exhibit both breadth and depth of knowledge in the academic areas that comprise the Social Sciences. The curriculum for Social Science generally contains social, historical, political, geographical, and ecological fields of study, which are being treated under many perspectives taking into account possible links to other subjects. The present Social Science curriculum considers competencies that are in line with the aspects of education for the twentyfirst century. Not only is information acquisition at the center, but so is the development of the student's personality and mindset [50].
The connection of topic knowledge, subject-specific didactics, and pedagogical psychology are especially significant in the setting of Social Science [51]. With its unique structure and didactics, it provides a wide foundation for action-oriented, character-forming learning through projects. This includes off-site learning places, activities, and events. According to Conrad and Kalcsics [52], social science students must make their own decisions, behave autonomously in social situations, and reflect on their actions. Giesinger [53] asserts the presence of modern autonomy, which is required to transform children into social agents. They must accept responsibility for themselves and their community and actively engage in the creation of their living environment. With research-based or problem-based learning in social science education, is very useful in shaping meaningful experiences, empathy, and social sensitivity [54], and hence, enhancing the student's potential.

The human capital theory [34], primarily thinks that formal education is vital and required for improving a population's productive potential. It stresses the importance of education in developing a person's productive capacity and self-efficacy through improving their reasoning skills. Entrepreneurial human capital is described in this context as one entrepreneurial attitude and abilities. Individual autonomy, risk, effort, and income are elements of entrepreneurial attitudes, whereas entrepreneurial abilities encompass opportunity identification, viability assessment, and innovative problem-solving abilities [20]. With this entrepreneurial human capital, we argue that one can develop sensitivity in recognizing market trends, consumer behavior, and developing excellent marketing strategy; which all these three aspects are the concept of marketing mindset. Based on this, we propose:

P2 = Social Science Education has positive and significant influence on Marketing Mindset

$P 3=$ Social Science Education has positive and significant influence on Entrepreneurial Interest P4 = Social Science Education has positive and significant influence on Entrepreneurial Interest, intervened by Marketing Mindset

\subsubsection{External Environment, Social Science Education, and Marketing Mindset}

This paper employs social constructivism [38-41] as a ground in relation to the external environment variable. The principle of social constructivism may be summarized as follows: Knowledge is actively produced by the learner rather than passively absorbed from the environment. This response to other epistemologies promotes fundamental communication conceptions as the straightforward transfer of meanings from one person to another. The learner's existing information is required to "actively" create new knowledge. Factors like social 
relationships, community, education, technology, geography, culture, economic conditions, and political systems will expose someone to various life experiences, resulting in varying 'knowledge' of marketing and perspective of entrepreneurial activities as a whole. A learner's social world comprises individuals who directly impact them, such as parents, instructors, friends, and participants in many types of activities.

Cobb [38] investigates whether the "mind" is located in the head or social activity and suggests that both viewpoints should be utilized in tandem since they are equally helpful. What seems to one as the logic of a group of individuals mutually adjusting to one other's behaviours may appear to another as the norms and practices of a classroom community [40]. Teaching techniques that use social constructivism as a reference point include teaching in situations that are personally relevant to students, negotiating taken as shared meanings with students, class discussion, small-group engagement, and emphasizing meaningful activities above right answers [39]. Constructivism-related methods are becoming more prevalent in scientific and mathematical courses but have been utilized far longer in humanities subjects such as social studies and communication.

Beyond the immediate social setting of a learning condition, there is a larger backdrop of cultural influences, such as custom, religion, technology, tools, political systems, and language. The tools that people use have an impact on how they think (by tools, it includes language and other symbolic systems as well as physical tools). According to Salomon and Perkins [41], tools have two effects on the learning mind. To begin, they shift the cognitive burden of a task between people and the tool while it is in use. A product description, for example, may save lengthy explanations, and using a social media chat room can alter the tone of a conversation. Second, using a tool may alter the mind beyond its actual usage by altering skills, perspectives, and ways of perceiving the world. Computers, for example, contain a complete philosophy of knowledge building, symbol manipulation, design, and exploration that, when utilized in an educational environment, may subversively encourage changes in curriculum, evaluation, and other changes in teaching and learning. Based on this, we propose:

P5 = External Environment has positive and significant influence on Social Science Education

P6 = External Environment has positive and significant influence on Marketing Mindset

P7 = External Environment has positive and significant influence on Entrepreneurial Interest, intervened by Marketing Mindset

\subsection{The Path Diagram of Research Variables}

The previous sections have presented conceptual explanations on how social science education drives the marketing mindset to shape entrepreneurial interest. Thus, in this section, we present the path diagram of this research variables (Figure 2) and the list of this research propositions.

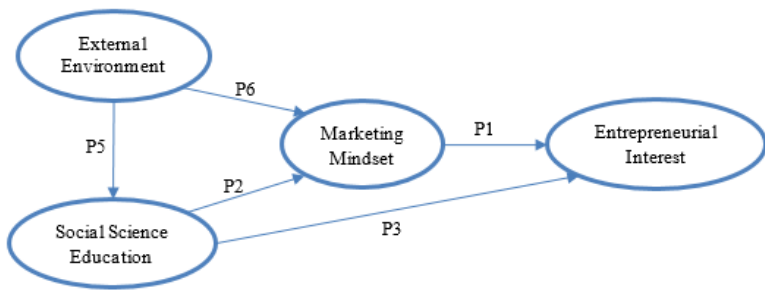

Figure 2 The path diagram of research variables.

Below are the list of this research propositions:

P1 = Marketing Mindset has positive and significant influence on Entrepreneurial Interest

$P 2=$ Social Science Education has positive and significant influence on Marketing Mindset

$P 3=$ Social Science Education has positive and significant influence on Entrepreneurial Interest

P4 = Social Science Education has positive and significant influence on Entrepreneurial Interest, intervened by Marketing Mindset

P5 = External Environment has positive and significant influence on Social Science Education

P6 = External Environment has positive and significant influence on Marketing Mindset

$P 7=$ External Environment has positive and significant influence on Entrepreneurial Interest, intervened by Marketing Mindset

\section{METHODS}

In developing the conceptual model, the methodology applied is qualitative. The main aim is to analyze the interaction between the external environment, social science education, and marketing mindset and the influence on entrepreneurial interest. We develop a model based on a literature review [55]. The researcher used Google Scholar and Microsoft Academics for article browsing by applying keywords such as "entrepreneurial interest," "entrepreneurial intention," "social studies influence on entrepreneurship," "social science education and entrepreneurship," and "marketing mindset." Following that, we offer the conceptual model based on a review of the literature.

\section{DISCUSSION AND CONCLUSION}

This study contributes to the existing literature on the conceptualization of social science education's influence on the marketing mindset and then on entrepreneurial interest by engaging the external factors, which is missing in the prior studies. Researchers could access the 
marketing mindset variable from the conceptual model that influences the empirical results in entrepreneurship research. The conceptual model complements entrepreneurial interest studies that did not mention the impact of the marketing mindset. This paper also taken into account a broader scientific family, specifically the social sciences to connect it with entrepreneurial interest. Academics and policymakers might also understand the importance of social studies in their own operational context.

This argue that the external environments influence the social science education and marketing mindset. Factors like social relationships, education, culture, community, technology, geography, economic conditions, and political system will expose someone to different experiences in life, resulting in different perceptions of marketing and entrepreneurial activities as a whole. Someone with limited ability to recognize consumer behavior, the market, and the current trend can struggle and find that entrepreneurial activity is hard, risky, and unattractive. In contrast, someone with a good marketing mindset can have the confidence to practice entrepreneurship. Thus, it can build their interest in entrepreneurship as this paper supported the notion that marketing mindset mediated the influence of social science education on entrepreneurial interest. Yet, empirical studies are needed to examine this argument.

\section{AUTHORS' CONTRIBUTIONS}

All authors provide equal contributions in the process of producing this article.

\section{ACKNOWLEDGMENTS}

The paper is part of a research project funded by Institute for Research and Community Service (LPPM) and Postgraduate Department of Universitas Negeri Surabaya.

\section{REFERENCES}

[1] Barba-Sánchez V, Atienza-Sahuquillo C. Entrepreneurial intention among engineering students: The role of entrepreneurship education. European Research on Management and Business Economics. 2018, 24(1): 53-61. URL: https://www.sciencedirect.com/science/article/pii/S 2444883417300220

[2] Nowiński W, Haddoud MY, Lančarič D, Egerová D, Czeglédi C. The impact of entrepreneurship education, entrepreneurial self-efficacy and gender on entrepreneurial intentions of university students in the Visegrad countries. Studies in Higher Education. 2019, 44(2): 361-79. DOI: https:// doi.org/10.1080/03075079.2017.1365359
[3] Wibowo SF, Purwana D, Wibowo A, Saptono A. Determinants of entrepreneurial intention among millennial generation in emerging countries. International Journal of Entrepreneurship. 2019, 23(2):1-10.

[4] Bjørnskov C, Foss NJ. Economic freedom and entrepreneurial activity: Some cross-country evidence. Public Choice. 2008, 134(3-4): 307-28. DOI: https://doi.org/10.1007/s11127-007-9229-y

[5] Tung DT, Hung NT, Phuong NTC, Loan NTT, Chong S-C. Enterprise development from students: The case of universities in Vietnam and the Philippines. The International Journal of Management Education. 2020, 18(1): 100-333.

[6] Turkina E, Thi Thanh Thai M. Social capital, networks, trust and immigrant entrepreneurship: a cross-country analysis. Journal of Enterprising Comm. 2013, 7(2): 108-24. DOI: https:// doi.org/10.1108/17506201311325779

[7] Harms R. Self-regulated learning, team learning and project performance in entrepreneurship education: Learning in a lean startup environment. Technological Forecasting and Social Change. 2015, 100: 21-8.

[8] Jung YS, Jung HY. The Structural Relationships among Undergraduates' Individual Characteristics, Startup Education, Startup-Relevant Knowledge and the Entrepreneurial Intentions. Asia-Pacific Journal of Business Venturing and Entrepreneurship. 2018, 13(6): 75-87.

[9] Mamun AA, Nawi NBC, Mohiuddin M, Shamsudin SFFB, Fazal SA. Entrepreneurial intention and startup preparation: A study among business students in Malaysia. Journal of Education for Business. 2017, 92(6): 296-314. DOI: https://doi.org/10.1080/08832323.2017.1365682

[10] Osakede UA, Lawanson AO, Sobowale DA. Entrepreneurial interest and academic performance in Nigeria: evidence from undergraduate students in the University of Ibadan. J Innov Entrep. 2017, 6(1): 19. DOI: https://doi.org/10.1186/s13731-017-00797

[11] Sarooghi H, Sunny S, Hornsby J, Fernhaber S. Design Thinking and Entrepreneurship Education: Where Are We, and What Are the Possibilities? Journal of Small Business Management. 2019, 57(1): 78-93. DOI: https://doi.org/10.1111/jsbm.12541

[12] Saptono A, Wibowo A, Narmaditya BS, Karyaningsih RPD, Yanto H. Does entrepreneurial education matter for Indonesian students' entrepreneurial preparation: The mediating role of entrepreneurial mindset and knowledge. Cheng M, editor. Cogent Education. 2020, 7(1): 1836728. URL: doi.org/10.1080/2331186X.2020.1836728 
[13] Bae TJ, Qian S, Miao C, Fiet JO. The Relationship between Entrepreneurship Education and Entrepreneurial Intentions: A Meta-Analytic Review. Entrepreneurship Theory and Practice. 2014, 38(2): 217-54. DOI: https://doi.org/10.1111/etap.12095

[14] Turner T, Gianiodis P. Entrepreneurship Unleashed: Understanding Entrepreneurial Education outside of the Business School: JOURNAL OF SMALL BUSINESS MANAGEMENT. Journal of Small Business Management. 2018, 56(1): 131-49. DOI: http://doi.org/10.1111/jsbm.12365

[15] Kallergis A, Lambelet Ale. Known quantity. Stanford Social Innovation Review. 2015. pp. 61-2.

[16] Semcow K, Morrison JK. Lean Startup for social impact: Refining the National Science Foundation's Innovation Corps model to spur social science innovation. SEJ. 2018, 14(3): 248-67. DOI: https://doi.org/10.1108/SEJ-02-2018-0013

[17] American Academy of Arts and Sciences. The Heart of the Matter: The Humanities and Social Sciences for a vibrant, competitive, and secure nation. American Academy of Arts \& Sciences. 2013. URL: https://www.amacad.org/news/heart-matterhumanities-and-social-sciences-vibrantcompetitive-and-secure-nation

[18] Zheng W. Research on Human Factors Affected College Teachers' Knowledge Collaborative Efficiency_ — Based on the Perspective of System Dynamics. In: 2016 International Conference on Social Science, Humanities and Modern Education (SSHME 2016). Atlantis Press; 2016. p. 87-94.

[19] Krugly-Smolska E. Cultural influences in science education. International Journal of Science Education. 1995, 17(1): 45-58. DOI: https://doi.org/10.1080/0950069950170104

[20] Fitzsimmons JR, Douglas EJ. Entrepreneurial attitudes and entrepreneurial intentions: a crosscultural study of potential entrepreneurs in India, China, Thailand and Australia. In: BabsonKauffman Entrepreneurial Research Conference. Wellesley, MA; $2005 . \quad$ URL: https://eprints.qut.edu.au/6486/1/6486.pdf

[21] Venesaar U, Kolbre E, Piliste T. Students' attitudes and intentions toward entrepreneurship at Tallinn University of Technology. Tutwpe. 2006, 154: 97 114.

URL: https://ideas.repec.org/p/ttu/wpaper/154.html

[22] Ismail M, Khalid SA, Othman M, Jusoff HK, Rahman NA, Kassim KM, et al. Entrepreneurial intention among Malaysian undergraduates. International Journal of Business and Management. 2009, 4(10): 54-60.

[23] Tong XF, Tong DYK, Loy LC. Factors influencing entrepreneurial intention among university students.
International journal of social sciences and humanity studies. 2011, 3(1): 487-96.

[24] Khan MM, Ahmed I, Nawaz MM, Ramzan M. Impact of personality traits on entrepreneurial intentions of university students. Interdisciplinary Journal of Research in Business. 2011, 1(4): 51-7.

[25] Iqbal A, Melhem Y, Kokash H. Readiness of the university students towards entrepreneurship in Saudi Private University: An exploratory study. European Scientific Journal. 2012, 8(15). URL: https://core.ac.uk/download/pdf/328023421.pdf

[26] Peng Z, Lu G, Kang H, others. Entrepreneurial intentions and its influencing factors: A survey of the university students in Xi'an China. Creative education. $2013, \quad 3(08)$ : $95 . \quad$ URL: https://www.scirp.org/html/26768.html

[27] Kume A, Kume V, Shahini B. Entrepreneurial characteristics amongst university students in Albania. European Scientific Journal. 2013, 9(16). URL: https://core.ac.uk/download/pdf/236410656.pdf

[28] Neneh BN. An assessment of entrepreneurial intention among university students in Cameroon. Mediterranean Journal of Social Sciences. 2014, 5(20): 542.

[29] Malebana MJ. Entrepreneurial intentions and entrepreneurial motivation of South African rural university students. Journal of Economics and Behavioral Studies. 2014, 6(9): 709-26. URL: https://ojs.amhinternational.com/index.php/jebs/arti cle/download/531/531

[30] Khuong MN, An NH. The factors affecting entrepreneurial intention of the students of Vietnam national university - a mediation analysis of perception toward entrepreneurship. Journal of Economics, Business and Management. 2016, 4(2): 104-11.

[31] Ayegba O, Omale SA. A study on factors affecting entrepreneurial development in Nigeria. European Journal of Business and Management. 2016, 8(12).

[32] Davidsson P. Determinants of entrepreneurial intentions. In: RENT XI Workshop. Piacenza, Italy; 1995.

URL: https://eprints.qut.edu.au/2076/1/RENT_IX.pdf

[33] Van Gelderen M, Brand M, Van Praag M, Bodewes W, Poutsma E, Van Gils A. Explaining entrepreneurial intentions by means of the theory of planned behaviour. Career development international. 2008, 13(6): 538-55. URL: http://citeseerx.ist.psu.edu/viewdoc/download?doi= 10.1.1.319.7008\&rep=rep $1 \&$ type $=$ pdf

[34] Becker GS. Human capital: A theoretical and empirical analysis, with special reference to education. University of Chicago press; 2009.

[35] Shapero A, Sokol L. The social dimensions of entrepreneurship. University of Illinois at Urbana- 
Champaign's Academy for Entrepreneurial Leadership Historical Research Reference in Entrepreneurship. 1982;

[36] Bandura A. Bandura Social foundations of thought and action. Englewood Cliffs, NJ: Prentice-Hall; 1986.

[37] Ajzen I. The theory of planned behavior. Organizational behavior and human decision processes. 1991, 50(2): 179-211.

[38] Cobb P. Where is the mind? Constructivist and sociocultural perspectives on mathematical development. Educational researcher. 1994, 23(7): 13-20.

[39] Wood T, Cobb P, Yockel E. Reflection on learning and teaching mathematics in elementary school. In: Steffe LP, Gale J, editors. Constructivism in education. Hillsdale, New Jersey: Lawrence Erlbaum, 1995. p. 401-32.

[40] Cobb P. Analyzing the mathematical learning of the classroom community: The case of statistical data analysis. In: Proceedings of the 22nd Conference of the International Group for the Psychology of Mathematics Education 1. University of Stellenbosch, South Africa: Citeseer; 1998. p. 3348. DOI: https: doi.org/10.1.1.914.404

[41] Solomon G, Perkins DN. Chapter 1: Individual and social aspects of learning. In: Pearson P, Iran-Nejad A, editors. Review of research in education. Washington, DC: American Educational Research Association; 1998. p. 1-24.

[42] Kumar G. Understanding institutions in the context of entrepreneurship. Journal of Entrepreneurship, Business and Economics. 2014, 2(2): 45-81. URL: http://scientificia.com/index.php/JEBE/article/dow nload/18/17

[43] Bharti K, Sharma V, Agrawal R, Sengar A. Marketer's mindset: Key to develop bottom of the pyramid market. Procedia-Social and Behavioral Sciences. 2014, 133: 169-79.

[44] Tollin K. Mindsets in marketing for product innovation: an explorative analysis of chief marketing executives' ideas and beliefs about how to increase their firms' innovation capability. Journal of Strategic Marketing. 2008, 16(5): 36390.

[45] Grunert KG, Trondsen T, Campos EG, Young JA. Market orientation in the mental models of decision makers: two cross-border value chains. International Marketing Review. 2010.

[46] Lee NR, Kotler PT. Marketing in the public sector: A roadmap for improved performance. Pearson Education; 2006.

[47] Fayolle A, Liñán F, Moriano JA. Beyond entrepreneurial intentions: values and motivations in entrepreneurship. International Entrepreneurship and Management Journal. 2014, 10(4): 679-89.
[48] Akmaliah Z, Pihie L, Arivayagan K. Predictors of entrepreneurial mindset among university students. International Journal of Humanities, Social Sciences and Education. 2016, 3(7):1-9.

[49] Shepherd DA, Patzelt H, Haynie JM. Entrepreneurial spirals: Deviation-amplifying loops of an entrepreneurial mindset and organizational culture. Entrepreneurship theory and practice. 2010, 34(1):59-82.

[50] Pröbstl G, Schmidt-Hönig K. Self-Efficacy in Social Science. Discourse and Communication for Sustainable Education. 2019, 10(2): 49-59. URL: https://www.sciendo.com/article/10.2478/dcse2019-0017

[51] Zadeh MV, Peschel M. SelfPro-Entwicklung von Selbstkonzepten beim Offenen Experimentieren [Development of self-concepts in open experimentation]. In: Franz U, Giest H, Hartinger A, Heinrich-Donges A, Reinhoffer B, editors. Handeln im Sachunterricht [Acting in social and science studies]. Bad Heilbrunn: Klinkhardt; 2018. p. 183 90.

[52] Conrad SJ, Kalcsics K. In der Welt handeln ìund das Paradox von Bilden und Partizipieren in der Schule [Acting in the world and the paradox of education and participation in schools]. In: Franz U, Giest H, Hartinger A, Heinrich-Donges A, Reinhoffer B, editors. Handeln im Sachunterricht [Acting in social and science studies]. Bad Heilbrunn: Klinkhardt; 2018. p. 37-44.

[53] Giesinger J. Kinder und Erwachsene [Children and adults]. In: Drerup J, Schickhardt C, editors. Kinderethik Aktuelle Perspektiven - Klassische Problemvorgaben [Ethics of children Contemporary perspectives - classical specifications]. Munchen: Mentis; 2017. p. 21-32.

[54] Nasution N, Sarmini S, Warsono W, Wasino W, Shintasiwi FA. Using Coping Strategies of Informal Sector Traders amid COVID-19 in Indonesia for Social Studies Teaching Materials on Realizing SDGs. Journal of Social Studies Education Research. 2021, 12(3): 144-74. URL: https://jsser.org/index.php/jsser/article/view/3173

[55] Marek MW. Conceptual Paper Outline. 2015. DOI: https://doi.org/ 10.13140/RG.2.1.4962.5768 